\begin{tabular}{|c|l|}
\hline Title & $\begin{array}{l}\text { DEVELOPMENT OF SINGLE BLA STOMERES FROM 4CELL STA GE EMBRY OS AFTER AGGREGATION } \\
\text { WITH PARTHENOGENONES IN MICE }\end{array}$ \\
\hline Author(s) & PINY OPUMMIN, A nuchai; TA KA HA SHI, Y oshiyuki; HISHINUMA, Mitsugu; KA NA GA WA, Hiroshi \\
\hline Citation & Japanese Journal of Veterinary Research, 42(3-4), 119-126 \\
\hline Issue Date & 1995-01-31 \\
\hline DOI & 10.14943/jvr.42.3-4.119 \\
\hline Doc URL & http:/hdl.handle.net/2115/2473 \\
\hline Type & bulletin (article) \\
\hline File Information & KJo0o02377741.pdf \\
\hline
\end{tabular}

Instructions for use 
Jpn. J. Vet. Res. 42(3-4) : 119-126 (1994)

\title{
DEVELOPMENT OF SINGLE BLASTOMERES FROM 4-CELL STAGE EMBRYOS AFTER AGGREGATION WITH PARTHENOGENONES IN MICE
}

\author{
Anuchai Pinyopummin, Yoshiyuki Takahashi, Mitsugu Hishinuma, \\ and Hiroshi Kanagawa
}

(Accepted for publication; Nov. 28, 1994)

\begin{abstract}
This study was undertaken to determine whether diploid parthenogenones can assist the development of single blastomeres of 4-cell embryos to term. Isolated blastomeres of 4-cell embryos were aggregated with parthenogenones at the 2-, 4- and 8-cell stages. After the removal of the zonae, aggregation was done by pushing one blastomere of 4-cell embryos and one parthenogenone into contact using a micropipette. There were no significant differences in the percentages of blastocysts and offspring among all parthenogenones' developmental stages used. It also seemed that the chimerism of the offspring (judged by coat color) was not affected by the developmental stage of the parthenogenone. A total of 19 offspring survived and 12 offspring were coat-colored chimera. From 12 coat-colored chimeric offspring, 9 offspring had germlines derived from the isolated blastomeres of 4-cell embryos, one offspring had a germline derived from both the parthenogenone and the isolated blastomere of a 4-cell embryo and one offspring had a germline derived from the parthenogenone. One offspring however, was infertile. The present study demonstrates that parthenogenones can be used to assist the development of single blastomeres from 4-cell embryos to term.
\end{abstract}

Key Words: Aggregation, 4-cell embryo, parthenogenone, mouse

\section{INTRODUCTION}

In the mouse, isolated blastomeres of 2-cell embryos can develop to term after transfer to recipients ${ }^{16)}$, but those of 4 - and 8-cell stages can not ${ }^{10,13)}$. However, it has been shown that isolated blastomeres of 4- and 8-cell embryos are totipotent and can contribute to both embryonic and extraembryonic tissues when they are combined

Department of Theriogenology, Faculty of Veterinary Medicine, Hokkaido University, Sapporo 060 , Japan 
with enough 'carrier' blastomeres to restore the normal cell number ${ }^{6}$.

Preimplantation development of mouse diploid parthenogenones does not appear to be different from that of normal fertilized embryos, but most parthenogenones die during gestation. This leads to the conclusion that the completion of mouse embryogenesis requires the presence of both the paternal and maternal genome ${ }^{5)}$.

Parthenogenetic $\longleftrightarrow$ fertilized mouse chimera studies have revealed that parthenogenetic cells can contribute to the trophectroderm and inner cell mass at the blastocyst stage ${ }^{1,15}$. Parthenogenetically derived cells are progressively eliminated during fetal development ${ }^{1,9)}$. They are absent from the extraembryonic tissues by about mid-gestation and later those in embryonic tissues come under selection ${ }^{9)}$. In adult chimeras, some parthenogenetically derived cells still persist and are preferentially found in specific tissues such as in the pigmentation of coat where they are found to be the largest participant and are consistently present. In the ovary and testis, they are found to have lower and sporadic distributions ${ }^{8}$.

Tsunoda et al. ${ }^{17)}$ have shown that diploid parthenogenones can be used to assist the development of one or two blastomeres from 8-cell embryos to term and that the proportion of chimeric offspring is low (10-20\%).

Our study was undertaken to determine whether diploid parthenogenones can assist the development of single blastomeres of 4-cell embryos to term. Effects of the developmental stage of the parthenogenones on the number and chimerism of offspring were also investigated.

\section{MATERIALS AND METHODS}

\section{Fertilized Embryos}

Slc : ICR female mice (coat color : albino) were superovulated with the injection of 5 IU pregnant mare serum gonadotropin (PMSG; Serotropin, Teikoku Zoki, Japan) followed $48 \mathrm{hr}$ later with $5 \mathrm{IU}$ human chorionic gonadotropin (hCG; Gonatropin, Teikoku Zoki, Japan) and mated with ICR male mice. Four-cell stage embryos collected 53-54 hr after hCG injection were used in the experiment.

Diploid Parthenogenones

F1 (C57BL/6 $\times$ CBA) female mice (coat color: agouti) were superovulated by injection of PMSG and hCG as described above. Unfertilized oocytes were collected 17.0-17.5 hr after hCG injection and were activated with $7 \%$ ethanol for $1 \mathrm{~min}^{12)}$. Then they were cultured in Whitten's medium (WM ${ }^{18)}$ supplemented with ethylenediaminetetra acetic acid disodium salt $\left(\mathrm{Na}_{2}\right.$ EDTA; $0.11 \mathrm{mM}$ ), bovine serum albumin (BSA; $3 \mathrm{mg} / \mathrm{ml}$ ) and cytochalasin-B $(\mathrm{CB}, 0.5 \mu \mathrm{g} / \mathrm{ml})$ for $5-6 \mathrm{hr}$ at $37^{\circ} \mathrm{C}$ in $5 \% \mathrm{CO}_{2}$ in air. Diploid parthenogenones with two pronuclei and without a second polar body were selected and cultured in the same medium without $C B$ until they reached the stage required. In this experiment, parthenogenones at the 2-cell (31-32 $\mathrm{hr}$ after activation), 4-cell (48-49 $\mathrm{hr}$ after activation) and 8-cell stages (53-54 hr after activa- 
tion) were used.

\section{Aggregation}

Zonae pellucidae of 4-cell embryos and parthenogenones were removed with acid Tyrode solution ( $\mathrm{pH} 2.7)^{4}$. The zona-free fertilized 4-cell embryos were disaggregated by incubating in $\mathrm{Ca}^{2+}$-free WM with BSA $(8 \mathrm{mg} / \mathrm{ml})$ for $1 \mathrm{hr}$ followed by repeated pipetting using a micropipette (inner diameter; $50 \mu \mathrm{m}$ ). One blastomere and one parthenogenone were placed in the same drop of $\mathrm{WM}+\mathrm{Na}_{2}$ EDTA $+\mathrm{BSA}$ and aggregated by pushing them into contact with a micropipette. There were at least 2 sites of cell contact in each case. About 15-30 minutes later, 4 aggregated embryos were transferred into a $25 \mu \mathrm{l}$ drop of the culture medium and 11 parthenogenones were added to increase embryo density ${ }^{11)}$. The aggregated embryos were further cultured in vitro for $40-52 \mathrm{hr}$ at $37^{\circ} \mathrm{C}$ in $5 \% \mathrm{CO}_{2}$ in air.

\section{Embryo Transfer}

Pseudopregnant ICR female mice were prepared by injection of PMSG and hCG to induce superovulation, and were mated with vasectomized male mice. All blastocysts obtained from the aggregated embryos were transferred to pseudopregnant mice (68-70 hr after hCG injection). The recipients were killed on Day 20 of pregnancy and the offspring were reared by foster mother mice.

\section{Chimerism of Offspring}

The chimerism of offspring that survived to adulthood was determined by coat color and germline. The germline was determined by mating with ICR male or female mice. If the progeny was albino, the germline was considered to have been derived from the isolated blastomere of 4-cell embryos and if the progeny was agouti, the germline was considered to have been derived from the parthenogenone.

\section{RESULTS}

The percentage of blastocysts and number of offspring obtained were not significantly different among 2-, 4- and 8-cell stage parthenogenones after aggregation with single blastomeres of 4-cell embryos (Table 1). Among the offspring that survived, the proportion of coat-colored chimera was high in all parthenogenones' developmental stages used $(60 \%$ from 2 -cell parthenogenones, $71 \%$ from 4 -cell parthenogenones and $57 \%$ from 8-cell parthenogenones) (Table 2, Fig. 1). After mating with ICR mice, all the coat-colored non-chimeric offspring gave albino progeny. However, from a total of 12 coat-colored chimeric offspring, 9 offspring gave only albino progeny, one offspring (No. 3) gave 2 agouti and 11 albino progeny (Fig. 2), one offspring (No. 16) gave only agouti progeny and one offspring (No. 6) was infertile. Thus, only a few coat-colored chimeric offspring (2 out of 11) expressed the parthenogenetic cells in the germlines. 
Table 1. Development of aggregated embryos between single blastomeres of 4-cell stage fertilized embroyos and one diploid parthenogenone.

\begin{tabular}{cccc}
$\begin{array}{c}\text { Parthenogenone } \\
\text { stage }\end{array}$ & $\begin{array}{c}\text { No. of aggregated } \\
\text { embryos }\end{array}$ & $\begin{array}{c}\text { No. of blastocysts } \\
\text { transferred (\%) }\end{array}$ & $\begin{array}{c}\text { No. of } \\
\text { offspring (\%) }\end{array}$ \\
\hline 2 -cell & 100 & $82(82.0)$ & $10(12.2)$ \\
4 -cell & 100 & $73(73.0)$ & $12(16.4)$ \\
8 -cell & 112 & $81(72.3)$ & $11(13.6)$ \\
\hline
\end{tabular}

Table 2. Characteristics of offspring obtained after transfer of aggregated embyos between single blastomeres of 4-cell stage fertilized embroyos and one diploid parthenogenone.

\begin{tabular}{ccccc}
\hline $\begin{array}{c}\text { Parthenogenone } \\
\text { stage }\end{array}$ & $\begin{array}{c}\text { Mouse } \\
\text { no. }\end{array}$ & Coat color & Sex & Germline* \\
\hline 2-cell & 1 & chimera & male & $\mathrm{F}$ \\
& 2 & chimera & male & $\mathrm{F}$ \\
& 3 & chimera & female & $\mathrm{F}+\mathrm{P}$ \\
& 4 & albino & male & $\mathrm{F}$ \\
& 5 & albino & female & $\mathrm{F}$ \\
\hline 4-cell & 6 & chimera & male & $\mathrm{NA}$ \\
& 7 & chimera & female & $\mathrm{F}$ \\
& 8 & chimera & female & $\mathrm{F}$ \\
& 9 & chimera & female & $\mathrm{F}$ \\
& 10 & chimera & female & $\mathrm{F}$ \\
& 11 & albino & male & $\mathrm{F}$ \\
& 12 & albino & female & $\mathrm{F}$ \\
\hline 8-cell & 13 & chimera & male & $\mathrm{F}$ \\
& 14 & chimera & male & $\mathrm{F}$ \\
& 15 & chimera & male & $\mathrm{F}$ \\
& 16 & chimera & female & $\mathrm{P}$ \\
& 17 & albino & male & $\mathrm{F}$ \\
& 18 & albino & male & $\mathrm{F}$ \\
& 19 & albino & female & $\mathrm{F}$ \\
\hline
\end{tabular}

${ }^{*} \mathrm{~F}$ : shows the expression of fertilized embryos.

$P$ : shows the expression of parthenogenones.

NA : data not available due to infertility. 


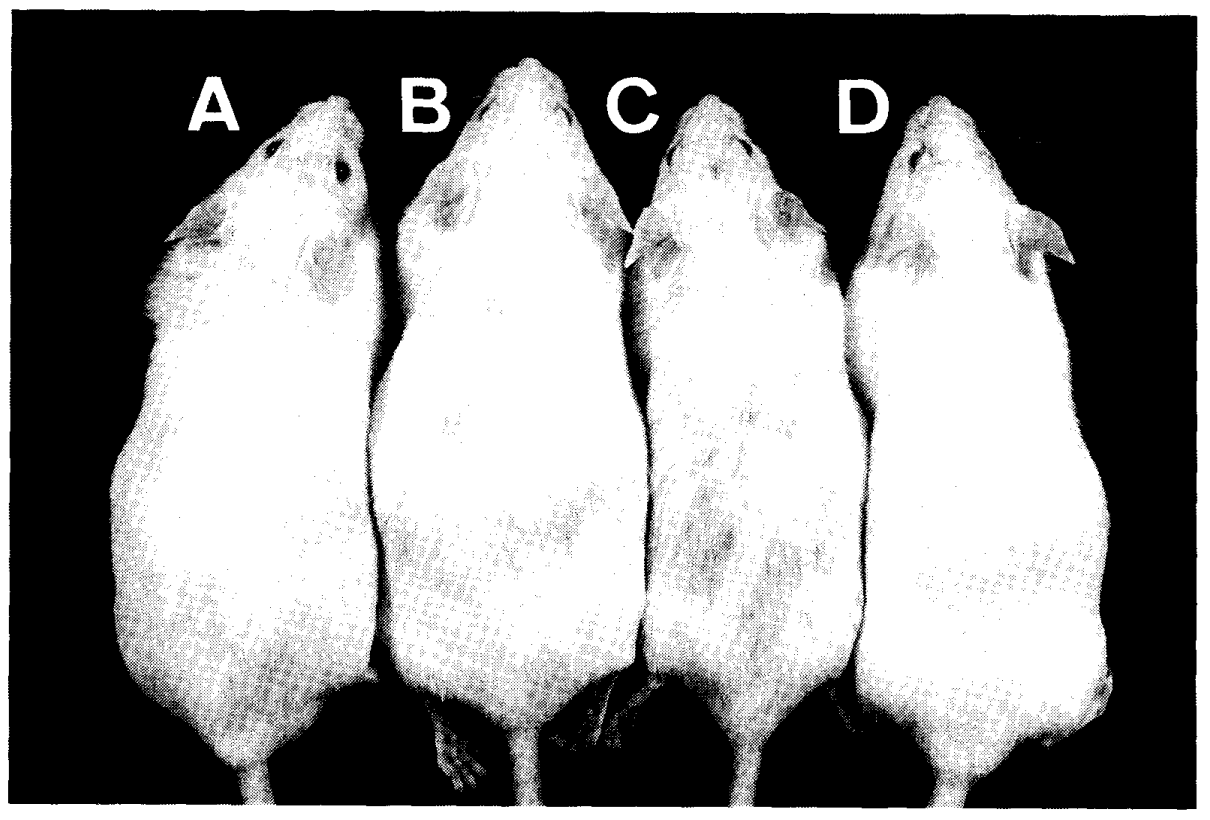

Fig. 1. The offspring obtained after transfer of aggregated embryos between single blastomeres of 4-cell stage fertilized embryos and one parthenogenone at 4 -cell stage. A, B,C) chimeric and D) non-chimeric offspring

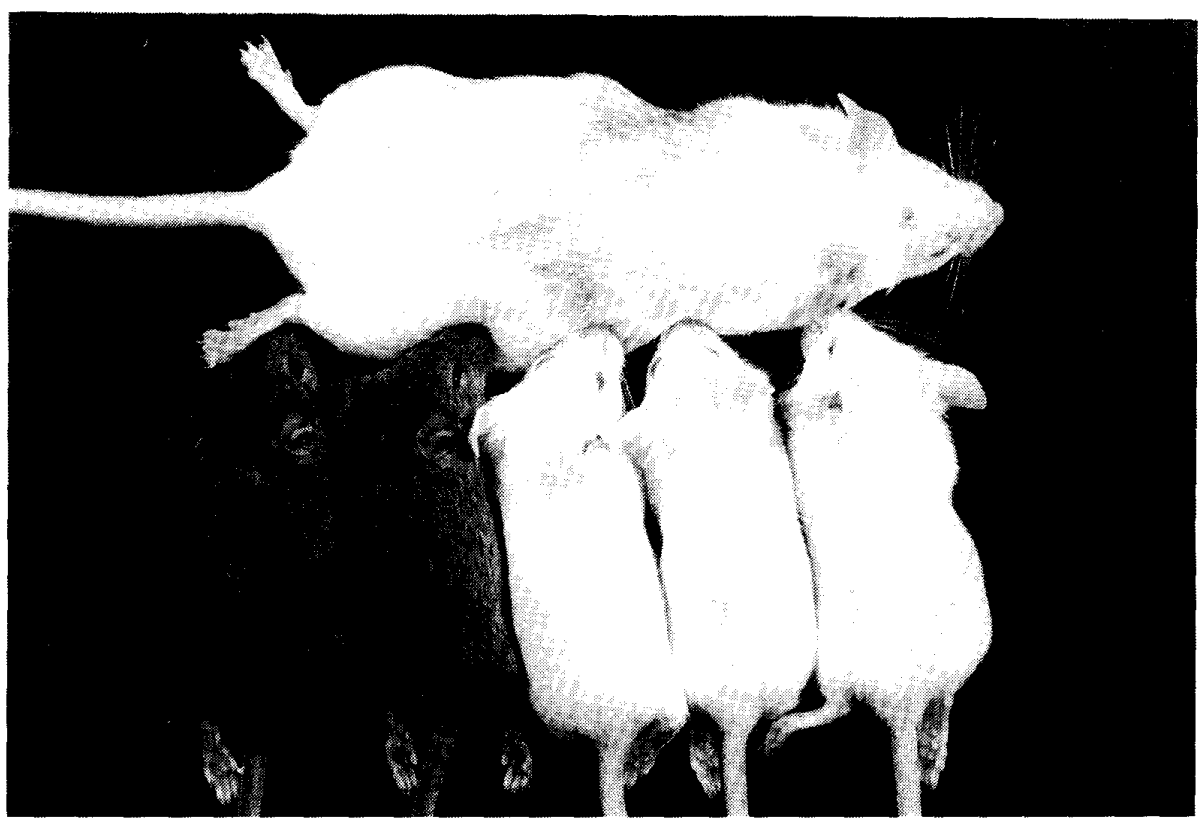

Fig. 2. The female chimeric offspring which gave both albino and agouti progeny after mating with an ICR male mouse (albino). 


\section{DISCUSSION}

The results demonstrate that diploid parthenogenones at the 2- to 8-cell stages can assist the development of single blastomeres of 4-cell stage embryos to term. The number and chimerism of offspring obtained did not seem to be affected by the developmental stage of the parthenogenone.

The inability of single blastomeres of 4-cell stage embryos to develop to term is suggested to be due to insufficient cells being present at cavitation ${ }^{13)}$. The parthenogenones may replenish this insufficiency by increasing the number of cells, since the parthenogenetic cells can contribute to both trophectoderm and inner cell mass $^{1,15)}$.

The developmental stage of the parthenogenone (2-, 4- and 8-cell) seemed to have no effect on the number of offspring obtained (Table 1). The ability to develop to term may be affected by the cell contribution of isolated blastomeres of 4-cell embryos to both the trophectoderm and inner cell mass at the blastocyst stage. Furthermore, the compensation mechanism for the regulation of the number of cells in the trophectoderm and inner cell mass appears in the 16 -cell stage ${ }^{2,7}$. Considering the developmental stage of the parthenogenone, the aggregation was done before the occurrence of the diversification of the inner cell mass and the trophectoderm. These may give the same probability to the isolated blastomeres for contributing cells to both the trophectoderm and inner cell mass in all the parthenogenones' stages used.

The cleavage rates of diploid parthenogenones and normal fertilized embryos were not significantly different ${ }^{3)}$. The parthenogenones used in this experiment were either synchronous or asynchronous with isolated blastomeres of 4 -cell embryos. It has been shown that in asynchronous aggregation chimeras between 4 -cell parthenogenones and 2-cell fertilized embryos, the proportion of parthenogenetic cells in embryos which were analysed at Day 10 of pregnency is higher than those of either 4-cell parthenogenetic and 4-cell fertilized, or 2-cell parthenogenetic and 4-cell fertilized embryos ${ }^{14)}$. However, the developmental stage of the parthenogenone (2-, 4and 8-cell) seemed to have no effect on the chimerism of offspring in our experiment (Table 2). This may have been caused by the smaller number of cells derived from fertilized embryos (one blastomere of 4-cell embryos). Thus, the parthenogenetic cells were dominant before the selection against parthenogenetic cells occurred.

Of the 11 fertile coat-colored chimeric offspring (Table 2), one offspring (No. 3) had a germline derived from both the parthenogenone and the isolated blastomere of a 4-cell embryo, while another (No. 16) had a germline derived from the parthenogenone. These results correlated well with the study of parthenogenetic $\longleftrightarrow$ fertilized mouse chimera ${ }^{8)}$, which indicates that the parthenogenetic cells in the ovary and testis have a lower and sporadic contribution compared to those in the pigmentation of the coat. 
In our experiment, the proportion of coat-colored chimeric offspring was higher than those obtained by Tsunoda et al. ${ }^{17)}$ in which two blastomeres of 8 -cell embryos were inserted within 4-cell parthenogenones from which one or two blastomeres had been removed. This was probably due to the higher proportion of blastomeres of parthenogenones used in our experiment (see Materials and Methods). However, the present study confirms that parthenogenones can be used to assist the development of isolated blastomeres of 4-cell stage embryos to term.

\section{ACKNOWLEDGEMENTS}

We thank Dr. J.A.N. Bautista for the helpful evaluation of this manuscript. This study was supported by Grants-In-Aid for Scientific Research (No. 0545412) from Ministry of Education, Science and Culture, Japan.

\section{REFERENCES}

1) Clarke, H. J. Varmuza, S., Prideaux, V. R. \& Rossant, J.: The developmental potential of parthenogenetically derived cells in chimeric mouse embryos: Implications for action of imprinted genes. Development 104: 175-182, 1988.

2) Fleming, T. P. : A quantitaive analysis of cell allocation to trophectoderm and inner cell mass in the mouse blastocyst. Dev. Biol. 119: 520-531, 1987.

3) Henery, C. C. \& Kaufman, M. H. : Cleavage rate of haploid and diploid parthenogenetic mouse embryos during the preimplantation period. Mol. Reprod. Dev. 31 : 258-263, 1992.

4) Hogan, B., Costantini, F. \& Lacy, E: Manipulating the Mouse Embryo. pp. 276. Cold Spring Harbor, New York, 1986.

5) Howlett, S. K., Barton, S. C., Reik, W. \& Surani, A. H. : Effects of nuclear parental origin on mouse development. In: Asch, R. H., BaLmacedA, J. P. \& Johnston, I. ed. Gamete Physiology, pp. 227-236. Serono Symposium, Massachusetts, 1990.

6) KelLy, S. J. : Studies of the developmental potential of 4- and 8-cell stage mouse blastomeres. J. Exp. Zool. 200 : 365-376, 1977.

7) Maro, B., Gueth-Hallonet, C., Aghion, J. \& Antony, C. : Cell polarity and microtubule organization during mouse early embryogenesis. Development Supplement $1: 17-25,1991$.

8) NaGY, A., SaSS, M. \& MARKKula, M. : Systemic non-uniform distribution of parthenogenetic cells in adult mouse chimeras. Development 106: 321-324, 1989.

9) Nagy, A., Paldi, A., Dezso, L., Varga, L. \& Magyar, A.: Prenatal fate of parthenogenetic cells in mouse aggregation chimeras. Development 101: 67-71, 1987.

10) Nakamura, K. \& Ishijima, Y. : Developmental potential of blastomeres isolated from 4 cell mouse embryos. J. Mamm. Ova Res. 6 : 1-5 (in Japanese), 1989.

11) Pinyopummin, A., Takahashi, Y., Hishinuma, M. \& Kanagawa, H. : In vitro development of mouse parthenogenetic embryos to blastocysts: Effect of embryo 
density. J. Reprod. Dev. 40: 55-58, 1994.

12) Pinyopummin, A., Takahashi, Y., Cheong, H. T., Hishinuma, M. \& Kanagawa, H. : Effect of cumulus cells and exposure period to ethanol on in vitro development of mouse diploid parthenogenoes. J. Vet. Med. Sci. 56: 379-380, 1994.

13) Rossant, J. : Postimplantation development of blastomeres isolated from 4- and 8-cell mouse eggs. J. Embryol. Exp. Morph. 36: 283-290, 1976.

14) Surani, M. A., Barton, S. C., Howlett, S. K. \& Norris, M. L. : Influence of chromosomal determinants on development of androgenetic and parthenogenetic cells. Development 103: 171-178, 1988.

15) Thomson, J. A. \& Solter, D. : Chimeras between parthenogenetic or androgenetic blastomeres and normal embryos: Allocation to the inner cell mass and trophectoderm. Dev. Biol. 131 : 580-583, 1989.

16) Tsunoda, Y. \& McLaren, A. : Effect of various procedures on the viability of mouse embryos containing half the normal number of blastomeres. J. Reprod. Fertil. 69 : 315-322, 1983.

17) Tsunoda, Y., Yasui, T., OKubo, Y., Nakamura, K. \& Sugie, T. : Development of one or two blastomeres from eight-cell mouse embryos to term in the presence of parthenogenetic eggs. Theriogenology 28 : 615-623, 1987.

18) Whitten, W. K. : Nutrient requirements for the culture of preimplantation embryos in vitro. Adv. Biosci. $6: 129-141,1971$. 